\title{
ENVIRONMENTAL-ECONOMIC ASPECT OF SUSTAINABLE DEVELOPMENT OF INDUSTRIAL ENTERPRISES OF REGIONS OF UKRAINE
}

\author{
Varlamova I.S. \\ Zaporizhzhia National University \\ Ukraine, 69600, Zaporizhzhia, Zhukovsky str., 66 \\ irina.varlamova.zp@gmail.com
}

Key words:

state regulation, environmental audit, environmental reporting, environmental management, economic space, environmental space, industrial enterprises, development.

\author{
ORCID 0000-0002-9921-3297
}

The features of development of industrial enterprises of Ukraine are considered in the article taking into account ecological-economic aspect. The advantages and disadvantages of integrating national industry into a single ecological and economic space are considered. The ways of restoration of potential, development of industrial regions of Ukraine are offered. The basic directions of development of industrial production which, should become the basis not only of formation of budgets of different levels, investment attractiveness of national producers, but also a basis for the development of regional and state programs of sustainable development, the program of taking of economy of Ukraine to a new qualitative level are singled out.

These problems are related to the improvement of the environment and its stabilization, the achievement of a balance between economic growth and the environmental situation, the creation and implementation of a system of rational use of natural resources. There is a need for a transition to intensive development, which involves finding ways to use existing resources rationally to meet the everincreasing needs of humanity. The article also gives directions of interaction of industrial enterprises with the public sector in order to prevent negative consequences and sustainable development of industrially loaded regions. The issues of state regulation of industrial development are covered. The task of socioeconomic development and the establishment of Ukraine as a high-tech state, asking into account the global experience of applying the environmental audit procedure in previous years, and to step up activities in this area in order to prevent environmental and economic crises in industrial regions. The stages of carrying out ecological audit are specified, in order to give greater economic attractiveness of industrial production of the region in the international markets and attraction of foreign partners.

The stages of carrying out ecological audit are specified, in order to give greater economic attractiveness of industrial production of the region in the international markets and attraction of foreign partners. The necessity of applying a rational combination in meeting the needs of mankind and breaking the ecosystem balance is highlighted.

\section{ЕКОЛОГО-ЕКОНОМЧЧИЙ АСПЕКТ СТАЛОГО РОЗВИТКУ ПРОМИСЛОВИХ ПІДПРИСМСТВ РЕГІОНІВ УКРАЇНИ \\ Варламова I.C.}

Запорізький національний університет

Україна, 69000, м. Запоріжжя, вул. Жуковського, 66

\section{Ключові слова:}

державне регулювання, екологічний аудит, екологічна звітність, екологічний менеджмент, економічний простір, екологічний простір, промислові підприємства, розвиток.
Досліджено особливості розвитку промислових підприємств України 3 урахуванням еколого-економічного аспекту. Розглядаються переваги й недоліки інтеграції національної промисловості в єдиний екологоекономічний простір. Запропоновано шляхи відновлення потенціалу, розвитку промислових регіонів України. Виокремлено основні напрями розвитку промислового виробництв, які повинні стати основою не тільки формування бюджетів різних рівнів, інвестиційної привабливості національних виробників, а й базою для розробки регіональних та державних програм сталого розвитку, програми виведення економіки України на новий якісний рівень. Ці проблеми пов'язані з поліпшенням стану навколишнього середовища та його стабілізацією, досягненням збалансованості між економічним зростанням $\mathrm{i}$ екологічною ситуацією, створенням та запровадженням системи раціонального використання природних ресурсів. Виникає необхідність переходу до інтенсивного розвитку, який передбачає пошук шляхів раціонального використання наявних ресурсів для задоволення постійно зростаючих потреб людства. Указуються напрями взаємодії промислових підприємств 3 державним сектором для запобігання негативним 
наслідкам та сталого розвитку промислово навантажених регіонів. Висвітлено питання державного регулювання розвитку промисловості $€$ створенням сучасного, інтегрованого у світове виробництво промислового комплексу, здатного в умовах інтеграції та глобалізації вирішувати основні завдання соціально-економічного розвитку та утвердження України як високотехнологічної держави, з урахуванням світового досвіду застосування процедури екологічного аудиту ще в попередні роки. Також слід активізувати діяльність у цьому напрямі для запобігання екологічної та економічної кризи в промислових регіонах. Конкретизовано етапи проведення екологічного аудиту для надання економічної привабливості промисловій продукції регіону на міжнародних ринках та залучення іноземних партнерів. Висвітлено необхідність застосування раціонального поєднання в задоволенні потреб людства та непорушенні балансу екосистеми.

\section{Statement of the problem}

It is well known that the main issue of the economy is to meet unlimited needs with limited resources. Considering that the growth rate of human needs is so great that it is impossible to meet them with the available resources. The question arises as to the rational use of available resources, since their number cannot be increased. Awareness of the direct link between socio-economic development in the country and the state of the environment has raised the question of humankind's need to find effective ways to simultaneously overcome the environmental crisis and achieve high rates of economic growth. These problems are related to the improvement of the environment and its stabilization, the achievement of a balance between economic growth and the environmental situation, the creation and implementation of a system of rational use of natural resources. There is a need for a transition to intensive development, which involves finding ways to use existing resources rationally to meet the everincreasing needs of humanity. At the same time, considerable attention is paid to the activity and development of industrial enterprises, which are: firstly, the most active subjects of environmental management; secondly, they create jobs, determine the level of material well-being; thirdly, they produce consumer goods that must be environmentally friendly and of high quality, because it depends on human health and the nation as a whole, which determines the level of human development and the country's competitiveness. Thus, there is a need to complement the existing theoretical research and practical approaches to the development of industrial enterprises to the characteristics of the internal and external environment, taking into account the economic and environmental aspect in which the formation and development of economic entities, and creates the preconditions for their effective functioning, and provides sustainable economic development of the country.

\section{Analysis of recent studies and publications}

The realities of today create the need for expansion of the production complex, due to the rapid growth of human needs, which has a significant impact on the environment. In this case, as a rule, the negative impact is mainly observed. All this creates a number of environmental problems and reduces the performance of business entities. Therefore, there is a need to develop effective economic mechanisms for regulating the activities and further development of enterprises, taking into account the environmental component. Therefore, the problem of greening the economy is urgent and is being researched by many domestic and foreign scientists, both from the theoretical and practical point of view.

Some aspects of ecological and economic regulation are explored in the works of such national scientists as: A. Antonyuk, A. Amosha, O. Baklatsky, O. Veklych, B. Danylyshyn, L. Melnyk, O. Novikov, A. Sadekov, Y. Stadnitsky, V. Hobt, V. Shevchuk and others [1-5]. Issues of rational environmental management at the enterprise level were considered by foreign scientists: K. Hoffman, S. George, N. Pakhomova, I. Potravny, K. Richter, G. Serov, M. Young [6-8]. Some aspects of optimization of ecological development of industrial complexes and introduction of market levers for their regulation were considered by M. Fujita and J.-F. Tiss, W., Henderson, K., Gors-Andersen, P. Guo, C. Mayo, G. Lee, and D. Chen [9]. Therefore, in today's context, a considerable number of questions need to be studied in detail to assess the impact of individual business entities on the natural equilibrium; creating the basis for the activation and development of industrial enterprises without disturbing the balance of ecosystems.

\section{Objectives of the article}

The purpose of the article is to investigate the peculiarities of the development of industrial enterprises taking into account the ecological and economic aspect in the process of integration of national industry into a single ecological and economic space.

\section{The main material of the research}

The current stage of development requires a radical change in management methods at both micro and macro levels. This is due to the need to take into account the environmental component in the organization of economic activity of industrial enterprises, because they are the most active participants in the economic life of the country. Although they have a negative impact on the environmental situation, they have many positive aspects: they create jobs, provide an adequate level of material well-being, create a separate environment for human development, and ensure local and state budgets.

This is due to the significant role of the industrial regions for the national economy, whose recovery and balanced functioning strengthen the state budget in terms of material security. Therefore, the state should undoubtedly be interested in supporting industrial regions in general and industrial enterprises in particular. To this end, it is necessary to activate and direct actions in the following directions: 
- state regulation of development and support of industrial regions;

- development and implementation of an environmental audit system;

- implementation of mandatory environmental reporting; - creation of a single economic and environmental space; - supporting and stimulating the development of industrial enterprises in a competitive environment and creating an industrial development system using innovative technologies;

- development of ecological and economic policy aimed at establishing and supporting proportions of industrial production, structure of production of finished environmentally friendly products in accordance with international standards;

- development of a system of long-term investment crediting; introduction of economic mechanisms for attracting investments in competitive industries;

- development of a system of state investment for the development of priority sectors that form the budget;

- development of foreign and domestic markets for industrial products;

- development of a system of training for industry, which involves the revision of the state order of these personnel, a system of encouragement for young professionals to obtain this knowledge and the development of a social policy system.

- formation and development of regional industrial policy taking into account ecological and economic problems of the region; introduction of social and environmental responsibility of industrial enterprises for the state of the environment and the state of health of the population.

The purpose of state regulation of the industrial development is to create a modern, integrated into the world production of the industrial complex, capable in the conditions of integration and globalization to solve the main tasks of socio-economic development and the establishment of Ukraine as a high-tech state. It envisages realization of tasks on activation of transformationalinstitutional and innovation-investment activity of industry with positive influence on its volumes and structure of production, acceleration of integration of industrial complex in world production.

The Government approved Concept of the project "National Targeted Economic Program for Industrial Development" for the period up to 2017 defines the option of solving these problems because of the targeted influence of the state on transformation processes and providing the most favourable conditions for reaching a new level of industry in terms of scale, institutional capacity, competitiveness efficiency, social orientation and environmental safety.

This project defines the directions of creation of favourable conditions for the development of industrial production, which are the main tasks of its state regulation. Such directions-tasks are: introduction of effective mechanisms of coordination and interaction of the state, regions, business and society in the formulation and implementation of industrial policy; further institutional changes in industry; formation of a new system of accelerated innovative development of industry; improving the structure of industrial production and its technological re-equipment; improvement of investment policy; development of domestic and foreign markets in the context of Ukraine's accession to the WTO; improvement of macroeconomic conditions of industry activity; development of human potential in industry; activation of regional industrial policy; stimulation of social orientation of industrial business; ensuring environmental safety [10].

One way to increase the efficiency of industrial enterprises and the prospects for their further development is to introduce environmental audits. The environmental audit procedure provides for several successive steps (Fig. 1).

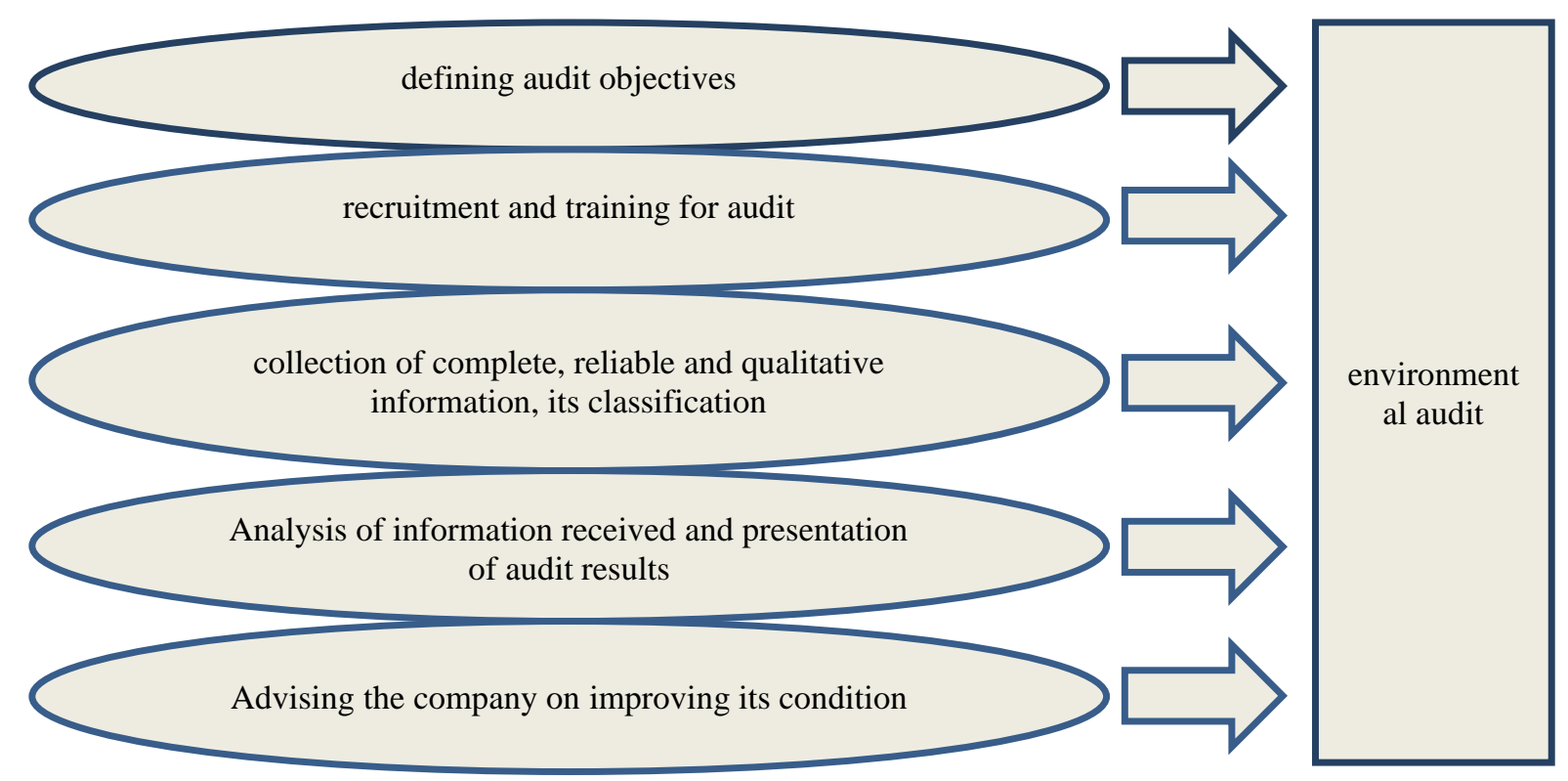

Fig. 1. Stages of carrying out ecological audit at the enterprise

It should be noted that environmental audits and approval of mandatory environmental reporting regulations encourage industrial enterprises to introduce environmental management systems and report on the 
environmental status of the enterprise. Introducing ecoreporting and making it available to a wide range of users will allow domestic industrial enterprises to join the world's environmental programs, namely the European Union's Environmental Management and Audit Program. Application of this stage will create conditions for more favourable conditions for integration of industrial enterprises into international markets.

Creating a single economic and environmental space will create and apply assessment standards for environmental and environmental impacts. These standards include ISO 14000, ISO 14001, which govern the environmental management and environmental audit procedures.

Taking into account the experience of the world states that have applied the environmental audit procedure in the 1970 s, our country should also intensify its activities in this area in order to prevent environmental and economic crisis in the industrial regions.

The peculiarity of the Ukrainian audit is that it is not compulsory for all enterprises, and the environmental audit report may contain recommendations on the steps to be taken to resolve the identified discrepancies. An environmental audit report is the property of its customer and the basis for its decision. Mandatory environmental audits are carried out at the request of the concerned executive or local self-government bodies on objects or activities that present an increased environmental hazard.

We need to introduce the UK, US experience where large companies are required to conduct environmental audits to increase investment attractiveness. In these countries, in order to obtain a loan, an enterprise must provide an ecoreport to a commercial bank. This report is analysed by banks to reduce the risk of bankruptcy and to increase the company's social responsibility for the environment.

The development and enhancement of economic efficiency of industrial enterprises of Ukraine depend (if not decisively) to a large extent on the national investment potential, which is formed at the expense of various financial sources, including foreign investments. Due to the crisis situation of most domestic enterprises and organizations, lack of own investment resources and intensive internationalization (integration) of production and economic systems, the increasing attraction of foreign investments becomes objectively necessary. Foreign investment can take many forms, depending on the type of investor, his purpose and the degree of risk he is prepared for.

The main types of foreign direct investment are usually: the creation of joint ventures; start-up of activities of subsidiaries (branches); conclusion of licensing agreements with domestic firms; acquisition of noncontrolling interests in domestic issuing companies. Joint ventures are created and managed jointly by foreign investors and local partners. Most often private companies are the ones, but sometimes state-owned companies may be.

Analysing the structure of the industrial complex of Ukraine, it should be noted that it is inefficient. This leads to overconsumption of natural resources and at the same time does not meet the basic needs of the economy, for example in investment resources, and the needs of the population - in services and goods, especially food, and also in consumer goods of durable use.

The general problem of industrial development of Ukraine remains the need to improve the structure of industrial production: increase in production volumes, as well as the range and quality of consumer goods; reducing the share of resource- and energy-intensive industries; implementation of scientific and technological progress in the production and further development of knowledgeintensive, relatively time-consuming industries (engineering, especially electronic, instrumentation, etc.); implementation of environmentally friendly technologies and equipment.

In-depth production intensification at all levels is also needed. The introduction of "high technology" is required both in the old, traditional industries (fuel and energy complex, ferrous metallurgy, chemical industry, heavy machinery, etc.), and in fundamentally new industries. This requires expanding the exchange of know-how with the highly developed countries of the world, introducing the experience of Ukraine's military-industrial complex (which is characterized by a relatively high level of NTP development). Improving the quality of final products, bringing them to world standards is the main condition for the Ukrainian industry to enter the world market.

Production of progressive products and use of already implemented advanced technologies are also reduced. Yes, continuous steel casting is only $6 \%$ of the total volume (in Japan this method is cast $100 \%$ steel). The production of rolled low-alloy steel with heat-treating is only $17.7 \%$ of total production. Production of polystyrene and copolymers decreased by 2 times, polyethylene 4 times, pipes and thermoplastic parts, truck tires, 4,6 times - rubber bands, 1,3 times - medicines.

These negative trends diminish Ukraine's potential to enter the world market. The share of mechanical engineering products (the main export industry of Ukraine for the future) decreased to $12 \%$ of total exports, including for the currency - to $2 \%$. In the structure of export of products, industries continue to be dominated by commodity industries and industries with a low level of processing of raw materials.

In recent years, the process of establishing joint ventures with the help of foreign countries with the best opportunities to enter the world market has begun. However, most of them work in the field of intermediary services.

Factors that limit the development of industry include the difficult demographic situation; negative environmental and social situation in large cities and industrial areas; shortage of fuel and energy, water, forest resources, nonferrous ores and some other types of raw materials; reduction of investments in new construction and reconstruction of old enterprises.

Factors that limit the development of industry include the difficult demographic situation; negative environmental and social situation in large cities and industrial areas; shortage of fuel and energy, water, forest resources, nonferrous ores and some other types of raw materials; reduction of investments in new construction and reconstruction of old enterprises. 


\section{Conclusions}

In recent years, the development of the Ukrainian industry has been chaotic, without defining and adhering to state priorities, in the absence of a well-thought-out state industrial policy and neglect of the environmental component. These years can be called a period of trial and error, when the transition to market relations was carried out by accelerated liberalization of both internal and external economic relations.
Neglect of the peculiarities of the state of the national market and the mechanical use in the macroeconomic policy of various inconsistent measures have led to the collapse of inflation, sharp decline of production and loss of control over economic activity in the country. The medium-term economic strategy did not take into account the systemic factors that begin to act in the transition of the economy from centralized planning to market orientation and affect production.

\section{References}

1. Novikova, O.F., Amosha O.I., Antoniuk V.P. (2012). Stalyi rozvytok promyslovoho rehionu: sotsialni aspekty [Sustainable development of the industrial region: social aspects]. Donetsk [in Ukrainian].

2. Veklych, O. O. (2000). Formuvannia ekonomichnoho mekhanizmu staloho rozvytku Ukrainy [Formation of economic mechanism of sustainable development of Ukraine], Visnyk NAU - Bulletin NAU, 2, 3-16. [in Ukrainian].

3. Melnyk, L.H. (2005). Osnovy staloho rozvytku [Fundamentals of sustainable development]. Sumy [in Ukrainian].

4. Natsionalna ekolohichna polityka Ukrayiny: otsinka i stratehiya rozvytku: (pidhotovleno v ramkakh proektu PROON/HEF «Otsinka natsionalnoho potentsialu v sferi hlobalnoho ekolohichnoho upravlinnya v Ukrayini») [National Environmental Policy of Ukraine: Assessment and Development Strategy (prepared as part of the UNDP / GEF Project «National Capacity for Global Environment Management in Ukraine»]. (2007). Kyiv [in Ukrainian].

5. Hofman, K. H. (1998). Ekonomyka pryrodopolzovanyia [Economics of nature management]. Moscow: Os [in Russian].

6. Pakhomova, N. V. (2001). Ekonomyka pryrodopolzovanyia y okhrany okruzhaiushchei sredy [Environmental Economics in Environmental Protection]. Sankt-Peterburh: Izdatel`stvo Sankt-Peterburgskogo universiteta [in Russian].

7. Potravny, j Y. M. Ekonomyka y orhanyzatsyia pryrodoyspolzovanyia [Economics and organization of nature management]. Moscow: Os [in Russian]

8. Serov, G.P. (2000). Ekolohycheskyi audyt [Environmental audit]. Moscow: Os [in Russian].

9. Fujita, M. (2004). Economics of Agglomeration: cities, industrial location and regional growth. Cambridge: Cambridge University Press

10. Salun, M. M. Rozvytok ukrainskykh promyslovykh pidpryiemstv: tendentsii ta problemy vidtvorennia modernizatsii [Development of Ukrainian industrial enterprises: trends and problems of reproduction of modernization]. Retrieved from http://www.sworld.com.ua/index.php/ru/economy-311/business-economics-andproduction-management-311/7696-ukrainian-news-rozvitok-promyslova-pdprimstv-tendents-an-issue-

vdtvorennya-s-modernzats. 